\title{
DL-malic acid supplementation improves the carcass characteristics of finishing Pelibuey lambs
}

José Lenin Loya-Olguin ${ }^{\mathrm{a}, \mathrm{c}}$

Fidel Ávila Ramos ${ }^{\mathrm{b}}$

Sergio Martínez Gonzalez ${ }^{\mathrm{c}}$

Iván Adrián García Galicia ${ }^{\mathrm{d}}$

Alma Delia Alarcón Rojo ${ }^{\mathrm{d}}$

Francisco Escalera Valente ${ }^{\mathrm{a}, \mathrm{c}^{*}}$

a Universidad Autónoma de Nayarit. Posgrado en Ciencias Biológico Agropecuarias, Tepic, Nayarit, México.

b Universidad de Guanajuato. Programa de Medicina Veterinaria y Zootecnia, Guanajuato, México.

c Universidad Autónoma de Nayarit. Unidad Académica de Medicina Veterinaria y Zootecnia. Compostela Nayarit, México.

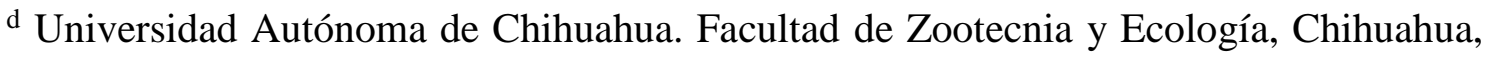
Chih. México.

*Corresponding author: franescalera@ hotmail.com

\begin{abstract}
:
The aim of the present study was to evaluate the effect of DL-malic acid addition in Pelibuey finishing diet on average daily gain, carcass characteristics and non-carcass components. Sixteen (16) male lambs with a mean body weight of $27 \pm 1.92 \mathrm{~kg}$, were used in a 48-d feeding experiment. Animals were fed a high-energy diet containing corn stover, as the only forage source, with and without the DL-malic acid (MA) addition. Animals were assigned randomly in two treatments with eight lambs each: 1) Addition of
\end{abstract}


$4 \mathrm{~g}$ of DL-malic acid per $\mathrm{kg}$ of feed and 2) Control (diet 1 without MA). Four male lambs of each treatment were harvested after feeding experiment to measure carcass characteristics and non-carcass components. Lambs fed with MA presented a larger $(P<0.05)$ Longissimus lumborum muscle area. Nevertheless, there were no effects $(P>0.05)$ of MA on daily average weight gain and non-carcass components weight. In conclusion, addition of $4 \mathrm{~g}$ DL-malic acid to a high-energy feed enhances muscle accretion, which improves carcass quality of finishing lambs.

Key words: Malic acid, Animal performance, Carcass characteristics.

Received: 30/03/2017

Accepted: 08/05/2018

Meat production is the main purpose ${ }^{(1)}$ of ovine farms in many regions of the world. While ovine meat quality can be improved under an intensive feed system utilizing high grain $\operatorname{diets}^{(2)}$, feed costs and ruminal disorders, mainly acidosis, increase. It is necessary to search for alternative feeding strategies to enhance the energy efficiency of rations and prevent metabolic disorders. Studies on malic acid (MA) have reported its ability to stimulate lactate utilization by Selenomonas ruminantium ${ }^{(3)}$, which can account for up to $51 \%$ of the total viable bacterial count in rumen ${ }^{(4,5)}$. MA has also been shown to cause increased $\mathrm{pH}^{(6)}$, microbial protein ${ }^{(3)}$ and total volatile fatty acid production ${ }^{(7)}$. Increases in $\mathrm{pH}$, total volatile acids and propionic acid had been observed utilizing ground corn and soluble starch to feed microorganisms in vitro ${ }^{(8)}$ since the hydrogen is utilized to convert malic acid to propionate ${ }^{(9)}$; decrease in hydrogen availability reduce the methane $\operatorname{production}^{(10)}$.

Results obtained with MA supplementation are not constant ${ }^{(11)}$. The roughage and concentrate proportions in rations influence the success of this additive ${ }^{(12)}$, with more favorable results being found with diets containing lower levels of forage ${ }^{(13)}$ in which MA is naturally present ${ }^{(14,15)}$. Limited in vivo research has been conducted to evaluate the effects of MA on ruminant performance ${ }^{(9,16)}$. Therefore, researchers recommend further studies to test its effects on lamb performance ${ }^{(2)}$.

Regarding with the influence of MA on carcass characteristics, there is evidence of an increase of hot carcass yield due to a greater average daily gain with malic acid inclusion in the concentrate of cross male lambs ${ }^{(17)}$, but, some authors have not found effect on carcass yield of heifers ${ }^{(18)}$. The authors of this study are not aware of information relating to the effects of DL-malic acid on the productive performance and carcass characteristics of Pelibuey, a hair sheep breed (HSB). 
The number of HSB has increased in several Latin American countries due to their ease of management and their resistance to parasites ${ }^{(19)}$ and elevated environmental temperature and humidity. However, HSBs have presented lower daily gain and poorer meat quality than wool breeds ${ }^{(20)}$. It should be noted that consumer demands for lean meats are increasing ${ }^{(21)}$. The objective of this study was evaluate the effect of DL-malic acid addition in the concentrated finishing diet of Pelibuey male lambs on average daily gain, carcass characteristics and non-carcass components.

Animal management procedures were conducted within the guidelines of locally approved techniques for animal use and care (NOM-051-ZOO-1995; humanitarian care of animals during mobilization of animals; NOM-062-ZOO-1995: technical specifications for the care and use of laboratory animals. Livestock farms, farms, centers of production, reproduction and breeding, zoos and exhibition hall must meet the basic principles of animal welfare; NOM-024-ZOO-1995; animal health stipulations and characteristics during transportation of animals.

This experiment was conducted at a commercial Pelibuey farm called Los Limones, located in Nayarit, Mexico (21 ${ }^{\circ} 03^{\prime} 48.11^{\prime \prime} \mathrm{N}$ and $\left.104^{\circ} 31^{\prime} 34.76^{\prime \prime} \mathrm{W}\right)$. Sixteen (16) male lambs with a mean body weight of $27 \pm 1.92 \mathrm{~kg}$ were used. Animals were divided randomly into two treatment groups of eight lambs each and placed in elevated pens with plastic slat flooring equipped with shade, feed and automatic waterers, with the two treatments comprising the addition of $4 \mathrm{~g}$ of DL-malic acid (MA) per $\mathrm{kg}$ of feed, and the control (the diet from the first treatment but without additive). The DL-Malic acid was purchased from the Sigma-Aldrich Chemical Company (St. Louis, MO, USA). Animals were fed ad libitum once daily at $0800 \mathrm{~h}$. The first $7 \mathrm{~d}$ were used for adaptation to treatment followed by a $48 \mathrm{~d}$ trial. The composition and ingredients of the experimental diets are shown in Table 1. Basal diet was prepared weekly. Batch was divided in two parts, and MA was added to one part; mixing MA with $20 \mathrm{~kg}$ of feed followed by the incorporation with the rest of the feed. 
Table 1: Ingredient and chemical composition of the experimental diets ${ }^{1}$

\begin{tabular}{lcc}
\hline Ingredient, \% & Control $^{\mathbf{2}}$ & MA $^{\mathbf{2}}$ \\
\hline Cracked corn & 12.48 & 12.43 \\
Sorghum grain & 53.05 & 52.84 \\
Canola meal & 9.82 & 9.78 \\
Soybean meal & $4.91 \mid$ & 4.89 \\
Cane molasses & 7.66 & 7.63 \\
Corn straw & 6.48 & 6.46 \\
Minerals & 2.95 & 2.94 \\
Calcium & 0.98 & 0.98 \\
Sodium bicarbonate & 0.69 & 0.68 \\
Grease & 0.98 & 0.98 \\
DL-malic acid & - & 0.39 \\
Chemical composition, \% & & \\
Dry matter & 88.70 & 89.09 \\
Crude protein & 14.01 & 13.95 \\
NE g, Mcal/kg & 1.14 & 1.13 \\
NE m, Mcal/kg & 1.77 & 1.76 \\
Crude fiber & 4.12 & 4.10 \\
Neutral detergent fiber & 16.44 & 16.37 \\
Acid detergent fiber & 5.76 & 5.74 \\
Ether extract & 3.88 & 3.87 \\
\hline
\end{tabular}

${ }^{1}$ Expressed on a dry-matter basis.

$\mathrm{NE} g=$ Net energy of gain.

$\mathrm{NE} m=$ Net energy of maintenance.

The daily feed allotments for each pen were adjusted to allow for minimal $(<5 \%)$ feed refusal at the feed bunk. Daily adjustments were undertaken to either increase or decrease daily feed delivery and weekly intake was recorded. One sample per week of the feed that had been offered to the animals was collected in order to determine dry matter content (DM, method 930,15) in accordance with the $\mathrm{AOAC}^{(22)}$.

Initial, weekly and final body weights were obtained after the animals' morning meal using an electronic scale (TOR REY TIL/S:107-2691, TORREY electronics Inc, Houston TX, USA). Body weight gains were calculated by subtracting the previous weight from the current weight, while the average daily body weight gains were calculated by dividing body weight gain by the number of days that had passed since the last weighing.

Four male lambs for each treatment were harvested in an ovine slaughterhouse (Asociación de Ovinocultores del Centro de Nayarit) after feeding period. Hot carcass weight was recorded immediately after animals were slaughtered. The carcasses were 
then covered with plastic to avoid cooling loss, and chilled for $24 \mathrm{~h}$ at $-4{ }^{\circ} \mathrm{C}$. Carcasses were ribbed between the 12th and 13th rib and back fat thickness measured with a metallic rule, with the Longissimus lumborum muscle then drawn on an acetate sheet in order to obtain the Longissimus muscle area (LMA) using a plastic grid.

Data was analyzed using a completely randomized design. The significance of the differences $(P<0.05)$ between treatment means were determined using the Student t-test for independent samples utilizing the SPSS software ${ }^{(23)}$.

The productive performance of finishing male lambs is shown in Table 2. In this study, lambs supplemented with DL-malic acid (MA) had similar $(P>0.05)$ average daily gains, feed intake, feed efficiency and initial and final body weight compared to the nonsupplemented ones.

Table 2: Productive performance of finishing Pelibuey male lambs

\begin{tabular}{lllll}
\hline Variable & Control $^{\mathbf{1}}$ & MA & SEM & P-value \\
\hline Days of feed & 48 & 48 & & \\
Male lambs, $\mathrm{n}$ & 8 & 8 & & \\
Initial BW, kg & 27.80 & 25.90 & 1.92 & 0.69 \\
Final BW, kg & 38.25 & 38.50 & 0.94 & 0.75 \\
DMI, g/d & 983 & 1022 & 64.75 & 0.69 \\
ADG, g/d & 218 & 263 & 58.05 & 0.87 \\
FE, g/g & 0.233 & 0.247 & 0.6 & 0.89 \\
\hline
\end{tabular}

${ }^{1}$ Control $=$ no malic acid supplementation.

$\mathrm{MA}=4 \mathrm{~g}$ of malic acid supplementation $/ \mathrm{kg}$ of feed; SEM= Standard error of the mean. $\mathrm{BW}=$ Body weight, $\mathrm{DMI}=$ dry matter intake; $\mathrm{ADG}=$ average daily gain; $\mathrm{FE}=$ feed efficiency.

The influence of MA on the lambs' carcass characteristics is presented in Table 3 . The addition of malic acid to male finishing diets did not alter $(P>0.05)$ hot carcass weight, back fat thickness (FT), or dressing percentage. Longissimus muscle area (LMA) was significantly $(P<0.01)$ larger in supplemented animals, while the MA did not affect noncarcass components (Table 4). 
Table 3: Carcass characteristics of Pelibuey male finishing lambs

\begin{tabular}{|c|c|c|c|c|}
\hline Variable & Control $^{1}$ & MA & SEM & $P$-value \\
\hline $\mathrm{HCW}, \mathrm{kg}$ & 21.5 & 21.3 & 0.67 & 0.87 \\
\hline Dressing $^{2}, \%$ & 56.2 & 55.3 & 0.81 & 0.23 \\
\hline $\mathrm{LL}$ area, $\mathrm{cm}^{2}$ & 11.8 & 13.0 & 0.42 & 0.002 \\
\hline Fat thickness, cm & 0.105 & 0.125 & 0.03 & 0.67 \\
\hline
\end{tabular}

${ }^{1}$ Control = no malic acid supplementation.

$\mathrm{MA}=4 \mathrm{~g}$ of malic acid supplementation $/ \mathrm{kg}$ of feed; $\mathrm{SEM}=$ standard error of the mean.

$\mathrm{HCW}=$ hot carcass weight; $\mathrm{LL}=$ Longissimus lumborum muscle.

${ }^{2}$ Dressing $=(\mathrm{HCW} /$ Final weight $) * 100$.

Table 4: Non-carcass components of Pelibuey male finishing lambs

\begin{tabular}{lllll}
\hline Variable $^{\mathbf{1}}$ & Control $^{\mathbf{2}}$ & MA & SEM & $\boldsymbol{P}$-value \\
\hline Skin & 11.04 & 12.16 & 0.52 & 0.08 \\
Feet & 2.15 & 2.19 & 0.66 & 0.77 \\
Heart & 0.48 & 0.51 & 0.05 & 0.60 \\
Liver & 2.25 & 2.26 & 0.15 & 0.92 \\
Lungs & 1.99 & 2.01 & 0.90 & 0.15 \\
Spleen & 0.30 & 0.38 & 0.01 & 0.06 \\
\hline
\end{tabular}

${ }^{1}$ Weight of each non-carcass component is expressed as a percentage of final body weight.

${ }^{2}$ Control $=$ no malic acid supplementation.

$\mathrm{MA}=4 \mathrm{~g}$ of malic acid supplementation $/ \mathrm{kg}$ of feed; $\mathrm{SEM}=$ Standard error of the mean.

Feed intake was similar for both groups 0.983 and $1.022 \mathrm{~kg}$ for the control and supplemented animals, respectively. Results of other authors show that malic acid does not alter the DMI of finishing lambs ${ }^{(2)}$, lactating Pelibuey ewes ${ }^{(24)}$, dairy goats ${ }^{(15)}$, dairy cows $^{(8,25,26)}$, and feedlot cattle ${ }^{(27)}$. Some authors mention that doses of MA lower than $2.6 \%$ do not affect $\mathrm{DMI}^{(28)}$. In this experiment, a $0.4 \% \mathrm{MA}$ level was evaluated because similar doses were used in previous research conducted with both the same ${ }^{(2,24)}$ and different breeds of sheep ${ }^{(11)}$.

Average daily gains (ADG) observed with MA corresponded to the mean weight for Pelibuey lambs fed high energy diets ${ }^{(29,30)}$. The null effect of MA on ADG in this experiment is in agreement with other reports on the MA supplementation of lambs ${ }^{(11 ; 31)}$ and bull calves ${ }^{(8)}$ fed with a high concentrate diet. However, some studies have reported the positive effect of MA on the daily live weight gain of cattle fed with a high concentrate $\operatorname{diet}^{(16)}$. Malate content varies with plant age (mature < early) and plant type (gramineous $<$ legumes) ${ }^{(32)}$. Therefore, a significant ADG increase was expected since lambs were fed with a high concentrate diet comprising only corn straw (which is low in malate content) as source of forage. Incorporation of DL-malate into soluble starch and cracked corn fermentations with mixed ruminal microorganisms have modify final $\mathrm{pH}, \mathrm{CH}_{4}$, and 
volatile fatty acids (VFA) in a manner analogous to ionophore effects ${ }^{(33)}$. However, according to this experiment, as other factors such as days on feed may influence the effects of MA, not only the concentrate forage ratio or type of grain should be criteria for the positive effects of this additive on ADG. The degree to which MA effects ADG may depends on diet composition ${ }^{(11)}$, in terms of grain type, dosage, chemical form (salt or free acid) or the productive stage of the animal ${ }^{(8)}$. MA levels ranging from 0.6 to $1.1 \%$ have enhanced the ADG of steers fed with high energy corn-based diets ${ }^{(34)}$. Also, steer ADG have increased linearly as more DL-malate was added to high energy diets based on rolled corn ${ }^{(16)}$. This study used a lower level of MA than $0.06 \%{ }^{(34)}$, due to the favorable results obtained in a previous experiment on lactating Pelibuey ewes fed with a similar diet $^{(24)}$. It is likely that significant differences could be found by prolonging the feeding experiment because ADG differences among treatments tended to be higher the more feeding days passed. However, in the region of Mexico where this study was conducted, retail customers, looking for leaner carcasses, prefer animals with a final body weight (FBW) of between 35 and $40 \mathrm{~kg}$.

Hot carcass weight $(\mathrm{HCW})$ and dressing percentage were not influenced by MA supplementation. Similarly, some researchers reported null effect of malate on HCW, cold carcass weight, and dressing percentage when it was added to a Merino lamb diet at 0.4 and $0.8 \%^{(11)}$.

The MA supplementation of finishing male lambs increased $(P=0.002)$ L. lumborum muscle area (LMA). Greater LMA is associated with higher yield and wholesale cuts of the carcass $^{(35)}$. Malate supplementation have increased nitrogen retention in sheep and steers ${ }^{(34)}$. Higher muscle growth may be attributed to an increase of microbial protein production $^{(3,36)}$, or to the high availability of propionate converted from the added MA as it 'sinks' $\mathrm{H}_{2}$ when reducing methanogenesis in rumen ${ }^{(7,37)}$. Both high nitrogen and propionate levels in rumen could increase muscle size firstly by depositing more nitrogen directly into the tissue, and secondly through the higher level of alanine bioavailability produced by the propionate metabolism through gluconeogenesis ${ }^{(38)}$. Moreover, higher amounts of propionate lead to the hypertrophy of intramuscular adipocites ${ }^{(39)}$ and bovine muscle $^{(40)}$. The use of propionate, a primary precursor for gluconeogenesis as energy for production has been documented mainly for milk synthesis. A significant effect of MA has been found in the milk protein yield from early lactation Pelibuey ewes ${ }^{(24)}$, early lactation dairy cows ${ }^{(28)}$, and mid lactation dairy cows ${ }^{(25)}$. This effect is attributed to an increase in microbial efficiency resulting from increased carbohydrate use for microbial $\mathrm{N}$ production ${ }^{(25)}$. However, propionate could also be used for higher muscle gain, as proposed in this study. Furthermore, percentage corresponding to each tissue may vary considerably among carcasses of similar weight, depending on the breed and type of feed $^{(41)}$.

Subcutaneous fat thickness (FT) was not different between treatments. It is likely that MA did not affect subcutaneous fat in Pelibuey sheep because hair sheep breeds deposit a small amount of subcutaneous fat ${ }^{(42)}$ and, most importantly, because the animals were harvested young when the fat deposition in pre-formed subcutaneous adiposities is not 
complete. In this case, higher amounts of ruminal propionate and, subsequently, glucose in the tissue does not result in the formation of higher levels of subcutaneous adiposities, as occurs with intramuscular adiposities ${ }^{(39)}$. Typically, body fat increases as harvest weights increase ${ }^{(43,44)}$. Thicker subcutaneous fat in Pelibuey lambs and a heavier final weight (>43 kg) have been reported ${ }^{(45)}$.

Smooth muscle growth was not affected by MA supplementation, with non-carcass components, expressed as a percentage of final body weight, similar for both treatments. These research results are in agreement with others authors, who found similar increases in total splanchnic tissue across the finishing phase that were consistent with similar rates of live and carcass gain observed in other studies ${ }^{(46)}$. There is a negative relationship between carcass residues (organs and offals) and carcass yield ${ }^{(47)}$. The weight of organs such as gastrointestinal tract and liver decrease during subnutrition periods ${ }^{(48)}$. Therefore, bigger differences in nutrients intake would be necessary to influence the weight of organs.

DL-malic acid supplementation (4 g per kilogram of feed) in finishing male Pelibuey lambs does not significantly improve average daily gain. While DL-malic acid supplementation does improve the Longissimus muscle area, it does not affect noncarcass components. Larger Longissimus muscle area could have a positive economic impact since it implies higher muscle proportion.

\section{Acknowledgments}

This work was financed by CONACyT (Consejo Nacional de Ciencia y Tecnologia) Project \# 147693.

\section{Literature cited:}

1. König EZ, Ojango JMK, Audho J, Mirkena T, Strandberg E, Okeyo AM, et al. Live weight, conformation, carcass traits and economic values of ram lambs of Red Maasai and Dorper sheep and their crosses. Trop Anim Health Prod 2017;(49):121129. 
2. González-Momita MI, Kawas JR, García-Castillo R, González-Morteo C, AguirreOrtega J, Hernández-Vidal G, et al. Nutrient intake, digestibility, mastication and ruminal fermentation of Pelibuey lambs fed finishing diets with ionophore (monensin lasalocid) and sodium malate. Small Ruminant Res 2009;(83):1-6.

3. Evans J, Martin SA. Factors affecting lactate and malate utilization by Selenomonas ruminantium. Appl Environ Microbiol 1997;(63):4853-4858.

4. Caldwell DR, Bryant MP. Medium without rumen fluid for nonselective enumeration and isolation of rumen bacteria. Appl Microbiol 1966;(14):794-801.

5. Nisbet DJ, Martin SA. Effect of a Saccharomyces cerevisiae culture on lactate utilization by the ruminal bacterium Selenomonas ruminantium. J Anim Sci 1991;(69):4628-4633.

6. Callaway TR, Martin SA. Effects of organic acid and monensin treatment on in vitro mixed ruminal microorganism fermentation of cracked corn. J Anim Sci 1996;(74):1982-1989.

7. Kung LJr, Huber JT, Krummrey JD, Allison L, Cook RM. Influence of adding malic acid to dairy cattle rations on milk production, rumen volatile acids, digestibility, and nitrogen utilization. J Dairy Sci 1982;(65):1170-1174.

8. Khampa S, Wanapat M. Supplementation of urea level and malate in concentrate containing high cassava chip on rumen ecology and milk production in lactating cows. Pak J Nutr 2006;(5):530-535.

9. Castillo C, Benedito JL, Pereira V, Vazquez P, Lopez AM, Mendez J, et al. Malic acid supplementation in growing/finishing feedlot bull calves: Influence of chemical form on blood acid-base balance and productive performance. Anim Feed Sci Tech 2007;(135):222-235.

10. Sarkar S, Mohini M, Nampoothiri VM, Mondal G, Pandita S. Effect of tree leaves and malic acid supplementation to wheat straw based substrates on in vitro rumen fermentation parameters. Indian J Anim Nutr 2016;(33):421-426.

11. Carro MD, Ranilla MJ, Giraldez FJ, Mantecon AR. Effects of malate on diet digestibility, microbial protein synthesis, plasma metabolites, and performance of growing lambs fed a high-concentrate diet. J Anim Sci 2006;(84):405-410.

12. Sirohi SK, Pandey P, Sinhi B, Goel N, Mohini M. Effect of malic acid supplementation on rumen fermentation, digestibility and methanogenesis in wheat straw sorghum based total mixed diets in vitro. Indian J Anim Sci 2012;(82):10381045. 
13. Foley PA, Kenny DA, Lovett DK, Callan JJ, Boland TM, O Mara FP. Effect of DLmalic acid supplementation on feed intake, methane emissions, and performance of lactating dairy cows at pasture. J Dairy Sci 2009;(92):3258-3264.

14. Muck RE, Wilson RK, O’Kiely P. Organic acid content of permanent pasture grasses. Irish J Agr Res 1991;(30):143-152.

15. Salama AAK, Caja G, Gardin D, Albanell E, Such X, Casals R. Effects of adding a mixture of malate and yeast culture (Saccharomyces cerevisiae) on milk production of Murciano-Granadina dairy goats. Anim Res 2002;(51):295-303.

16. Martin SA, Streeter MN, Nisbet DJ, Hill GM, Williams SE. Effects of DL- malate on ruminal metabolism and performance of cattle fed a high concentrate diet. J Anim Sci 1999;(77):1008-1015.

17. Díaz-Royón F, Arroyo JM, Alvir MR, Sánchez S, González J. Effects of protein protection with orthophosphoric or malic acids and heat on fattening lamb diets. Small Ruminant Res 2016;(134):58-61.

18. Carrasco C, Medel P, Fuentetaja A, Ranilla MJ, Carro MD. Effect of disodium/calcium malate or Saccharomyces cerevisiae supplementation on growth performance, carcass quality, ruminal fermentation products, and blood metabolites of heifers. J Anim Sci 2016;(94):4315-4325.

19. Avendaño-Reyes L, Macías-Cruz U, Álvarez-Valenzuela FD, Águila-Tepato E, Torrentera-Olivera NG, Soto-Navarro SA. Effects of zilpaterol hydrochloride on growth performance, carcass characteristics, and wholesale cut yield of hair-breed ewe lambs consuming feedlot diets under moderate environmental conditions. J Anim Sci 2011;(89):4188-4194.

20. Notter DR. Potential for hair sheep in the United Sates. J Anim Sci 2000;(77):1-8.

21. Dwyer CM, Lawrence AB, Bishop SC. The effects of selection for lean tissue content on maternal and neonatal lamb behaviors in Scottish Blackface sheep. Anim Sci 2001;(72):555-571.

22. AOAC. Official Methods of Analysis. $17^{\text {th }} \mathrm{ed}$. Washington, DC, USA: Association of Official Analytical Chemists. 2000.

23. SPSS. Statistical Package for the Social Sciences for Windows (Version 20.0). Armonk, NY: IBM Corp. 2011.

24. Martínez-González S, Escalera-Valente F, Gómez-Danés AA, Plascencia A, LoyaOlguin JL, Ramírez-Ramírez JC, et al. Influence of levels of DL-malic acid 
supplementation on milk production and composition in lactating Pelibuey ewes and pre-weaning weight gain of their suckling kids. J Appl Anim Res 2015;(43):92-96.

25. Sniffen CJ, Ballard CS, Carter MP, Cotanch KW, Dann HM, Grant RJ, et al. Effects of malic acid on microbial efficiency and metabolism in continuous culture of rumen contents and on performance of mid-lactation dairy cows. Anim Feed Sci Technol 2006;(127):13-31.

26. Khampa S. Effects of malate level and cassava hay in high-quality feed block on rumen ecology and digestibility of nutrients in lactating dairy cows raised under tropical condition. Int J Livest Prod 2009;(1):6-11.

27. Montaño MF, Chai W, Zinn-Ware TE, Zinn RA. Influence of malic acid supplementation on ruminal $\mathrm{pH}$, lactic acid utilization, and digestive function in steers fed high-concentrate finishing diets. J Anim Sci 1999;(77):780-784.

28. Wang C, Liu Q, Yang WZ, Dong Q, Yang XM, He DC, et al. Effects of malic acid on feed intake, milk yield, milk components and metabolites in early lactation Holstein dairy cows. Livest Sci 2009;(124):182-188.

29. Macías-Cruz U, Álvarez-Valenzuela FD, Rodríguez-García J, Correa-Calderón A, Torrentera-Olivera NG, Molina-Ramírez L, et al. Crecimiento y características de canal en corderos Pelibuey puros y cruzados F1 con razas Dorper y Katahdin en confinamiento. Arch Med Vet 2010;(42):147-154.

30. Plata FX, Hernandez PA, Mendoza GD, Martínez JA. Efecto de una $\alpha$ amilasa (ec 3.2.1.1) en el patrón de consumo y eficiencia productiva de corderos alimentados con una dieta alta en concentrado. Arch Med Vet 2015;(47):161-166.

31. Aksu ED, Sahin T, Kaya I, Unal Y. Effects of supplementation with different amounts of malic acid to Tuj lambs diets on fattening performance, rumen parameters and digestibility. Rev Med Vet 2012;(2):70-75.

32. Callaway TR, Martin SA, Wampler JL, Hill NS, Hill GM. Malate content of forage varieties commonly fed to cattle. J Dairy Sci 1997;(80):1651-1655.

33. Martin SA. Manipulation of ruminal fermentation with organic acids: a review. J Anim Sci 1998;(76):3123-3132.

34. Sanson DW, Stallcup OT. Growth response and serum constituents of Holstein bulls fed malic acid. Nutr Rep Int 1984;(30):1261-1267.

35. Shackelford SD, Cundiff LV, Gregory KE, Koohmaraie M. Predicting beef carcass cutability. J Anim Sci 1995;(73):406-413. 
36. Khampa S, Wanapat M, Wachirapakorn C, Nontaso N, Wattiaux MA, Rowlison P. Effect of Levels of Sodium DL-malate Supplementation on Ruminal Fermentation Efficiency of Concentrates Containing High Levels of Cassava Chip in Dairy Steers. Asian Australasian J Anim Sci 2006;(19):368-375.

37. Khampa S, Chaowarat P, Singhalert R, Wanapat M. Manipulation of rumen ecology by yeast and malate in dairy heifer. Pak J Nutr 2009;(8):787-791.

38. Ortigues I, Visseiche AL. Whole-body fuel selection in ruminants: nutrient supply and utilization by major tissues. P Nutr Soc 1995;(54):235-251.

39. Wan R, Du J, Ren L, Meng Q. Selective adipogenic effects of propionate on bovine intramuscular and subcutaneous preadipocytes. Meat Sci 2009;(82):372-378.

40. Hosseini A, Behrendt C, Regenhard P, Sauerwein H, Mielenz M. Differential effects of propionate or $\beta$-hydroxybutyrate on genes related to energy balance and insulin sensitivity in bovine white adipose tissue explants from a subcutaneous and a visceral depot. J Anim Physiol Anim Nutr (Berl) 2012;(96):570-580.

41. Ríos-Rincón FG, Bernal BH, Cerrillo SMA, Estrada AE, Juarez RAS, Obregon JF, et al. Carcass characteristics, primal cuts yields and tissue composition of Katahdin x Pelibuey lambs fed cull-chickpeas. Rev Mex Cienc Pecu 2012;(3):357-371.

42. Castellanos-Ruelas AF. Técnicas para estimar la composición corporal. En: Técnicas de Investigación en Rumiología. Primera ed. México DF. México. Consultores en producción animal. 1990:257-267.

43. Owens FN, Gill DR, Secrist DS, Coleman SW. Review of some aspects of growth and development of feedlot cattle. J Anim Sci 1995;(73):3152-3172.

44. Partida PJA, Martínez RL. Body composition in Pelibuey lambs in terms of feed energy concentration and slaughter weight. Vet México 2010;(41):177-190.

45. Ríos-Rincón FG, Estrada-Angulo A, Plascencia A, López-Soto MA, Castro-Pérez BI, Portillo-Loera JJ, et al. Influence of protein and energy level in finishing diets for feedlot hair lambs: growth performance, dietary energetics and carcass characteristics. Asian Austral J Anim Sci 2014;(27):55-61.

46. Hersom MJ, Krehbiel CR, Horn GW, Hersom MJ, Horn GW, Krehbiel CR, et al. Effect of live weight gain of steers during winter grazing: II. Viceral organ mass, cellularity, and oxygen consumption. J Anim Sci 2004;(82):184-197.

47. Ruiz-Ramos J, Chay-Canul AJ, Ku-Vera JC, Magaña-Monforte JG, GómezVázquez A, Cruz-Hernández A, et al. Carcass and non-carcass components of 
pelibuey ewes subjected to three levels of metabolizable energy intake. Ecosistemas y Recursos Agropecuarios 2016;(3):21-31.

48. Martins SR, Chizzotti ML, Yamamoto SM, Rodrigues RTS, Busato KC, Silva TS. Carcass and non-carcass component yields of crossbred Boer and Brazilian semiarid indigenous goats subjected to different feeding levels. Trop Anim Health Prod 2014;(46):647-653. 